\title{
PReS-FINAL-2008: Juvenile dermatomyositis: a report of 22 cases
}

\author{
A Souto $^{1 *}$, N Alvarez ${ }^{2}$, A Barros ${ }^{1}$, L Fernandez 1 , B Lopez ${ }^{3}$, I Calvo ${ }^{4}$ \\ From 20th Pediatric Rheumatology European Society (PReS) Congress \\ Ljubljana, Slovenia. 25-29 September 2013
}

\section{Introduction}

Juvenile dermatomyositis is a chronic inflammatory muscular disease that affects every year 1.5-3 children permillion and also produces systemic, skin, joint, digestive and respiratory manifestations.

\section{Objectives}

To describe the main epidemiological, clinical andanalytical aspects of Juvenile dermatomyositis diagnosed in La Fe Hospital (Valencia, Spain).

\section{Methods}

Patients diagnosed of Juvenile dermatomyositis in La Fe Hospital (Valencia, Spain) since June 1992 to March 2013. Dates are shown in median and interquartile range for non-parametric variables, and for parametric variables is given as mean and standard deviation. To assess response to treatment, we used Wilcoxon test for paired measures of non-parametric variables and $t$-student for parametric variables.

\section{Results}

We included 22 patients, $45.5 \%$ women, age at diagnosis 7.6 (3.7-10.8) years and evolution time 2.75 (1-5) months.

The most frequent initial manifestation were muscle weakness (40\%) and skin alterations (40\%). Also constitutional symptoms (15\%) and myalgia (5\%). They presented muscle weakness (100\%), heliotrope rash (100\%), Gottron papules (90.9\%), calcinosis (27.3\%), other skin lesions such as telangiectasias, oral ulcers, livedo reticularis and purpura (55.5\%), mialgia (55.5\%), arthralgia (55.5\%), arthritis (50\%), constitutional symptoms (50\%), esophageal involvement (31.8\%), gastrointestinal (28.6\%), Raynaud (18.2\%),

${ }^{1}$ Hospital Clinico Santiago Compostela, Santiago de Compostela, Spain Full list of author information is available at the end of the article fever (27.3\%), anasarca (18.2\%), dysphonia (18.2\%), and lung disease (18.2\%).

Patients were treated with corticosteroids, immunoglobulins and immunosuppressants such as methotrexate, tacrolimus, cyclosporine and antimalarial, alone or in combination, with significant improvement.

CPK at diagnosis was $1114 \mathrm{UI} / \mathrm{I}(280-4952)$, and 73 (46106) after 3 months, with significant improvement ( $\mathrm{p}=$ 0.0010). Aldolase at diagnosis $15.45 \mathrm{U} / \mathrm{L}$ (12-37) and 6 (410)after 3 months $(\mathrm{p}=0.0148)$. GOT at diagnosis $149 \mathrm{U} / \mathrm{L}$ (73-180) and $28(25-38)$ after a year $(\mathrm{p}=0.0005)$. GPT at diagnosis $102 \mathrm{U} / \mathrm{L}$ (44-187) and 23 (17-36) after a year (p $=0.0003)$. ESR at diagnosis $18 \mathrm{~mm}$ (16-36.5) and 13 (7-18) after a year $(\mathrm{p}=0.0139)$. Strength at diagnosis was $2.5 \pm 1$ and $4.25 \pm 0.87$ after 3 months $(\mathrm{p}<0.00001)$.

Capilarocopy was realised in most of patients at diagnosis and showed pathological capillary patterns (decrease in the number of capillaries, enlargement, megacapillaries, and bleeding), with improvement in subsequent assessments.

\section{Conclusion}

Dermatomyositis is a rare disease of childhood. Children we presented had muscle weakness and heliotrope erythema (100\%) and in varying proportions Gottron's papules, calcinosis, Raynaud, artromialgias and general symptoms. We propose a comprehensive patient monitoring, assessing muscle strength and laboratory findings as CPK, aldolase, GOT, GPT and ESR but also by capillaroscopy. Capillaroscopy may be indicative of dermatomyositis outbreak, has diagnosis value and may observe an early improvement pattern when patients are in remission.

\section{Disclosure of interest}

None declared. 


\section{Authors' details}

'Hospital Clinico Santiago Compostela, Santiago de Compostela, Spain.

${ }^{2}$ Hospital Universitario A Coruña, A Coruña, Spain. ${ }^{3}$ Hospital La Fe Valencia,

Valencia, Spain. ${ }^{4}$ Hospital La Fe Valencia, Santiago de Compostela, Spain.

Published: 5 December 2013

doi:10.1186/1546-0096-11-S2-P21

Cite this article as: Souto et al:: PReS-FINAL-2008: Juvenile

dermatomyositis: a report of 22 cases. Pediatric Rheumatology 2013

11(Suppl 2):P21.

Submit your next manuscript to BioMed Central and take full advantage of:

- Convenient online submission

- Thorough peer review

- No space constraints or color figure charges

- Immediate publication on acceptance

- Inclusion in PubMed, CAS, Scopus and Google Scholar

- Research which is freely available for redistribution

Submit your manuscript at 